\title{
ANÁLISE DO CRESCIMENTO URBANO NO MUNICÍPIO DE SAPUCAIA DO SUL/RS E AS TENDÊNCIAS ATUAIS DE EXPANSÃO URBANA
}

\section{ANALYSIS OF URBAN GROWTH IN THE MUNICIPALITY OF SOUTH SAPUCAIA / RS AND THE CURRENT TRENDS OF URBAN EXPANSION}

\author{
Felipe de Sousa Gonçalves ${ }^{1}$ \\ Nina Simone Vilaverde Moura²
}

\begin{abstract}
Resumo
Este artigo se propõe a analisar a expansão urbana sobre o relevo do Município de Sapucaia do Sul, Estado do Rio Grande do Sul. Os procedimentos adotados foram pesquisa em instituições públicas, saídas de campo e trabalhos em laboratório, além de publicações que auxiliaram na compreensão da dinâmica socioeconômica da cidade no seu processo histórico de evolução, analisando o período de 1930 a 2010. De forma a subsidiar outros estudos que tenham como mote o ambiente e o relevo, a geomorfologia atende aos requisitos de uma visão sistêmica da paisagem, abordando e relacionando questões referentes à sociedade e à natureza. A partir de uma espacialização daquilo que pode e não pode ser ocupado na cidade, é possível perceber que nem tudo, em um território, tem que cumprir alguma função urbana, apesar de que, das áreas onde a cidade está assentada hoje, apenas 4,69\% pode ser considerado inadequado. As cidades têm suas limitações e o ser humano não tem o total controle sobre elas. Acredita-se que Sapucaia do Sul alcançou o limite do crescimento urbano, iniciando agora um período de rearranjo espacial dentro do município, levando a outra configuração urbana.
\end{abstract}

Palavras-Chave: Sapucaia do Sul/RS; Geomorfologia; Planejamento Urbano.

\begin{abstract}
This article aims to analyze the urban expansion on the relief of the city of Sapucaia do Sul, State of Rio Grande do Sul. The procedures adopted were research in public institutions, field trips and work in the laboratory, as well as publications that helped in understanding the socio-economic dynamics of the city in its historical process of evolution, analyzing the period from 1930 to 2010. In order to support other studies that have as their theme the environment and relief, geomorphology meets the requirements of a systemic view of the landscape, addressing and issues relating to society and to nature. From a spatial distribution of what can and can not be occupied in the city, you can see that not everything in a territory has to meet some urban function, though, the areas where the city sits today only 4,69\% can be considered inappropriate. Cities have their limitations and the human being does not have full control over them. It is believed that South Sapucaia reached the limit of urban growth starting rearrangement now one period within the municipality, leading to another urban setting.
\end{abstract}

Keywords: Sapucaia do Sul / RS; geomorphology; Urban planning.

\footnotetext{
${ }^{1}$ Doutorando em Geografia pela Universidade Federal do Rio Grande do Sul. Instituto Canoas XXI (Prefeitura Municipal de Canoas).E-mail: felipesousars@gmail.com

${ }^{2}$ Doutorado em Geografia (Geografia Física) pela Universidade de São Paulo (2001). Atualmente é professora do Departamento de Geografia da Universidade Federal do Rio Grande do Sul. Faz parte do Programa de PósGraduação em Geografia da Universidade Federal do Rio Grande do Sul (mestrado e doutorado). E-mail: nina.moura@ufrgs.br
} 


\section{INTRODUÇÃO}

Inserido numa região metropolitana, o Município de Sapucaia do Sul, Estado do Rio Grande do Sul, está sujeito aos desafios geralmente encontrados em regiões urbanas do Brasil e da América Latina, especialmente as metropolitanas. Além da complexidade intrínseca à área de estudo, esse artigo tem a intenção de estabelecer uma relação entre a natureza e a sociedade, intensificando os desafios e objetivos a serem alcançados.

Na prática, o Brasil apresentou intenso processo de urbanização seguindo a tendência de países da América Latina. As cidades médias metropolitanas, segundo Amorim e Serra (1997), contribuíram para os grandes fluxos migratórios. A alternativa encontrada na época por estes migrantes, segundo os autores, foi o seu deslocamento para as áreas periféricas do núcleo central da metrópole devido ao elevado custo de vida nessas áreas, principalmente, das moradias, que os levava a preferir se fixar nas cidades de menor porte populacional, ou seja, cidades médias metropolitanas. Conforme Thouret (2007),

A cidade latino-americana é caracterizada pela segregação socioespacial das classes ricas, que vivem reclusas nos guetos; das classes médias, que habitam os bairros extensos, muito heterogêneos; e de uma maioria de pobres e de imigrantes, que contribuem para a expansão de cinturões precários e heterogêneos. (...) A heterogeneidade do tecido urbano segmentado em todas as escalas caracteriza a cidade latinoamericana e encontra sua origem nas etapas históricas de seu desenvolvimento, a começar da República ou mesmo da Colônia. (THOURET, 2007, p. 90).

Ao estudar a expansão urbana de uma cidade sobre o relevo, surge uma complexidade de fatores que envolvem outras áreas da geografia para que se possam explicar determinados fenômenos da natureza. Para isso, o entendimento da dinâmica do relevo, segundo Ross (2005), interessa diretamente ao homem como ser social.

Muitos exemplos de que a combinação natureza e sociedade pode ser trágica são vistos pelo Brasil. Percebe-se, diante de tragédias urbanas, que não houve planejamento durante a ocupação dessas áreas e tampouco foram identificadas anteriormente, evidenciando a ausência do Estado naquilo que é de sua responsabilidade. Isso porque, segundo Santiago et al (2008),

A interação do homem e do ambiente natural resulta na criação da paisagem, um conjunto de características relacionadas entre si que conferem o diferencial de cada localidade. O processo de criação da paisagem não é de forma alguma estático, mas acompanha a evolução da sociedade. (SANTIAGO et al, 2008, p. 252). 
Para conhecer as regiões que, não apenas são vulneráveis a eventos extremos, mas a qualquer outra situação de risco que se queira estudar ou identificar, os mapeamentos são peças fundamentais para que se possa ter a conjuntura regional com as informações necessárias para o devido estabelecimento de diretrizes em intervenções.

Diante dos fatores levantados e dos objetivos que serão perseguidos na apresentação desse artigo, cita-se Swyngedouw (2009), que salienta o seguinte:

A cidade e o processo urbano são uma rede de processos entrelaçados a um só tempo humanos e naturais, reais e ficcionais, mecânicos e orgânicos. Não há nada "puramente" social ou natural na cidade, e ainda menos antissocial ou antinatural; a cidade é, ao mesmo tempo, natural e social, real e fictícia. Na cidade, sociedade e natureza, representação e ser são inseparáveis, mutuamente integrados, infinitamente ligados e simultâneos; essa "coisa" híbrida social-natural chamada "cidade" é cheia de contradições, tensões e conflitos. (SWYNGEDOUW, 2009, p. 100).

A partir de situações que envolvem a ocupação urbana sobre o relevo e como essas situações se apresentam, este artigo propõe-se, como objetivo principal, analisar a expansão urbana do Município de Sapucaia do Sul - RS sobre as formas de relevo, estudo apresentado conforme os seguintes objetivos: estabelecer relações entre a Geomorfologia e o Planejamento Urbano; compor a situação legal vigente a partir de legislações ambientais e urbanísticas; indicar as tendências de crescimento urbano do município, a partir da caracterização histórica da ocupação.

\section{Justificativa}

O Município de Sapucaia do Sul está inserido na Região Metropolitana de Porto Alegre (RMPA) (figura 1) e conta com 130.988 habitantes (destes, apenas 488 na zona rural), distribuídos em 58,644 km², conforme o Censo 2010 do IBGE. Localizado 25 km ao norte da capital do Estado do Rio Grande do Sul, Porto Alegre, Sapucaia do Sul faz divisa ao norte com os municípios de Novo Hamburgo e São Leopoldo, a leste com os municípios de Gravataí e Cachoeirinha, ao sul com o Município de Esteio e a oeste com os municípios de Nova Santa Rita e Portão.

Seu principal rio é o dos Sinos, cujos afluentes em Sapucaia do Sul são os arroios José Joaquim, Mem de Sá, Moinho, Boa Vista e dos Cassel; e ainda o arroio Sapucaia que é o limite intermunicipal entre os municípios de Esteio e Canoas. Os pontos de maiores altitudes são o morro Sapucaia com 285 m, o morro das Cabras (divisa com o Município de Gravataí), com 287m e o morro do Paula (divisa com os municípios de Novo Hamburgo e São Leopoldo), com 306m. 
Localização de Sapucaia do Sul - RS.

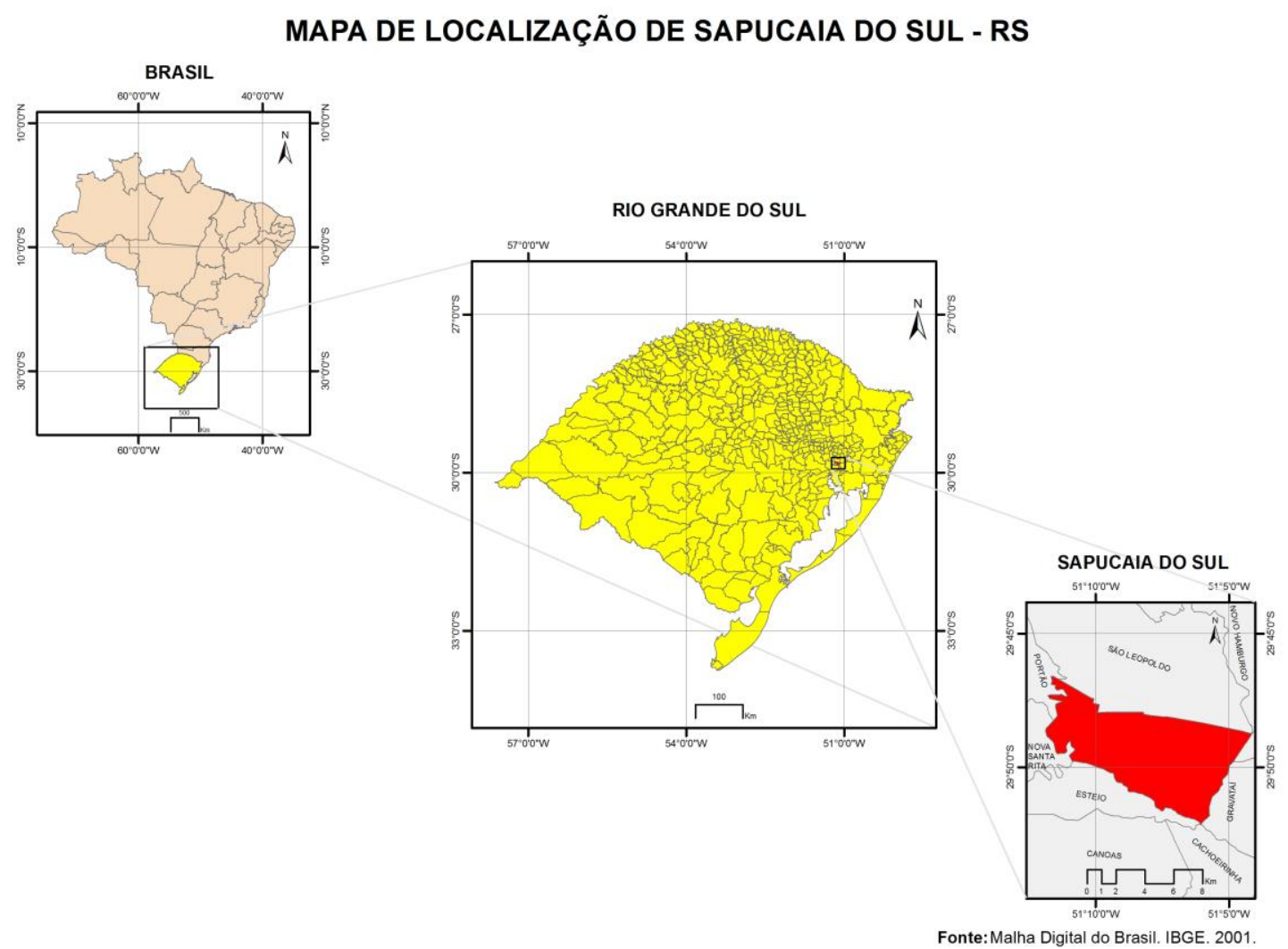

Elaboração: os autores.

Embalado pelas diferentes épocas e modos de migração, a construção de Sapucaia do Sul está atrelada aos movimentos da população. O "inchaço" dado pela ocupação vertiginosa, principalmente na Década de 1970, trouxe consequências, muitas delas irreparáveis. São visíveis as regiões da cidade que tiveram a sua ocupação até essa década, onde se percebem as ruas numa disposição lógica, com avenidas largas delimitando bairros e ligando-as a outros eixos viários. Após esse período, houve um abandono no planejamento da cidade, sendo as áreas ocupadas após essa época aquelas onde existem, possivelmente, as maiores chances de ocorrerem algum evento de risco ambiental.

O resultado desse descaso é que existem cerca de $60 \%$ da população que vive em situação de irregularidade fundiária no município, ou seja, moradias que não constam em loteamentos oficiais. Sapucaia do Sul tem um déficit de 6,46\% do total de domicílios permanentes, o que representaria 2.352 habitações, colocando o município em 14으 no ranking dos municípios da RMPA e, considerando os números absolutos, ficaria em 8 o em déficit habitacional, conforme estudos da Fundação João Pinheiro. 
O planejamento ambiental e territorial, a partir de conceitos geográficos, segundo Amaral e Ross (2006), deve atentar às características naturais da área e sua suscetibilidade aos problemas ambientais e sociais. Um estudo detalhado do meio físico é um instrumento eficaz de gestão territorial, visto que, com base nessas informações podem ser definidas áreas que acomodariam, com menor impacto, um adequado uso do solo.

O crescimento rápido e desordenado que tem ocorrido em muitas cidades é o grande responsável pelas transformações ambientais, conforme Guerra e Marçal (2006). A Geomorfologia Urbana procura compreender em que medida essas transformações do meio ambiente, causadas pelo homem, podem ser responsáveis pela aceleração de certos processos geomorfológicos, proporcionando uma nova morfodinâmica.

Entretanto a natureza separada da sociedade não possui significado, conforme Casseti (1991). Segundo o autor, a natureza sempre é relacionada material e idealmente com a atividade social. A forma de apropriação e transformação da natureza responde pela existência dos problemas ambientais, cuja origem encontra-se determinada pelas próprias relações sociais.

Além disso, Munhoz (2005) diz que o urbano é o lugar e manifestação da divisão do trabalho na sociedade. Segundo a autora, a contribuição marxista serviu para contrapor o espaço na temática urbana à visão que considera aquele como ambiente natural e inerte, como um recipiente para atividades econômicas, investimentos, pessoas.

Sendo assim, as cidades não são compostas apenas de ruas, casas, prédios e pessoas. Elas são sim o reflexo de ideologias que demarcam território à medida que os interesses econômicos são favoráveis. Ainda segundo Casseti, "a atividade do homem entra em relação produtiva e cognoscitiva com a natureza através do trabalho, o que o difere dos demais animais; ele transforma a natureza em objeto da própria consciência teórica" (CASSETI, 1991, p. 15).

É evidente a necessidade de uma política de planejamento e de um arranjo territorial que considere as influências das variáveis do meio físico-biótico. É desejável que, conforme Ross (2005), uma política de planejamento físico-territorial, quer seja do país, estado ou município, se processe de modo a compatibilizar os interesses imediatos e necessidades futuras do homem como ser humano individual e social.

Do ponto de vista de planejamento ambiental e territorial, observando a dinâmica dessa região, poderá ser verificada a atual conjuntura e a busca de soluções, não só de médio e longo prazo, mas também sugestões para que tais problemas possam ser minimizados dentro de um tempo menor. A partir de algumas diretrizes técnicas, seria possível definir intervenções práticas no cotidiano da cidade a fim de minimizar futuros problemas da urbanização que estariam condicionadas ao relevo. 
Diante disso, a proposição principal desse estudo é analisar a ocupação urbana sobre o relevo, trazendo elementos para buscar um melhor ordenamento territorial desse município metropolitano gaúcho, de forma que a identificação de locais para a implantação de novas ocupações, com equipamentos públicos, incluindo os de moradia popular, possa ser atrelada ao sítio urbano, verificadas no conjunto da cidade.

Portanto, neste estudo será apresentado a ocupação urbana atual do Município de Sapucaia do Sul e as possibilidades de ocupação do seu território a partir de um conjunto de índices regulamentados em legislação municipal, estadual e federal. A partir desses índices foi possível estabelecer em quais áreas do município são passíveis de ocupação urbana, independente do uso final a ser dado.

Aliar sociedade e natureza em apenas um estudo oportuniza uma radiografia completa das dinâmicas de uma cidade do porte de Sapucaia do Sul. A partir disso, muitos dos problemas apontados durante a instalação e expansão desse município poderão contar com um diagnóstico e proposições que, no futuro, se possam estabelecer parâmetros que respeitará as áreas de importância ambiental não ocupada atualmente. É uma contribuição a uma cidade com ares metropolitanos. A construção social sobre a natureza é complexa e dinâmica, justamente por estar atrelada às questões econômicas e, sobretudo, às políticas públicas. O sujeito dessa história - o ser humano - modifica a natureza que Ihe rodeia, ao ritmo das distintas conjunturas macro e microeconômicas.

\section{PRESSUPOSTOS TEÓRICOS}

\section{Geomorfologia e o Urbano}

A Geomorfologia é uma ciência geográfica do campo da Geografia Física que faz interface com a Geografia Humana, uma vez que trabalha com questões sociais representadas em territórios e ocupações assentadas sobre o relevo. Para tal, a Geomorfologia traz o estudo do relevo para diversas áreas do conhecimento, como planejamento urbano e regional, análise ambiental e áreas de risco. Esta ciência utiliza-se de conceitos de morfoestrutura e morfoescultura a fim de fazer distinção das diferentes formas do relevo. A partir de fatores endógenos são formados os elementos morfoestruturais do relevo, e dos fatores exógenos os elementos morfoesculturais.

A Geomorfologia, segundo Ross (2005), ao ser uma das áreas das Geociências e estar na interface litosfera-atmosfera-hidrosfera-biosfera, tem importante papel a desempenhar nos estudos ambientais. Suas aplicações voltam-se para o planejamento ambiental, planejamento regional, planos diretores municipais, bem como aos Estudos de Impactos Ambientais (EIA) e Relatórios de Impactos 
Ambientais (RIMA) para a implantação de grandes obras de engenharia civil, complexos industriais, núcleos de assentamentos agrários, instalação de núcleos urbanos, complexos portuários, aeroviários, entre outros.

Todavia, as mudanças econômicas e tecnológicas afetam construções, e a manutenção do uso do solo na cidade que, por sua vez, influenciam os processos geomorfológicos. Jorge (2011) refere-se ainda à medida que o caráter socioeconômico de uma cidade se altera existe uma resposta geomorfológica para a qual a política urbana deve estar atenta. As transformações que vêm ocorrendo de forma acelerada na construção urbana têm relação com o crescimento, comum nas grandes e médias cidades, visto que seu desenvolvimento, muitas vezes, não obedece aos condicionantes biofísicos do lugar original de implantação.

A Geomorfologia contribui com o planejamento urbano, uma vez que as cidades se assentam sobre o relevo e, ao conhecer a dinâmica dele, é possível identificar melhores locais para a ocupação urbana. O levantamento geomorfológico visa mostrar como as formas de relevo influenciam na escolha e na delimitação de locais adequados à expansão urbana e na formação da paisagem, indo ao encontro dos autores já abordados.

Entretanto, as questões ambientais estiveram fora de pauta durante o início da formação de muitas cidades, levando-as a uma ocupação desordenada e irracional do espaço geográfico, desencadeando um desequilíbrio entre as potencialidades ambientais e as necessidades da população. Moura (2011) destaca que :

A análise geomorfológica torna-se um importante instrumento para a compreensão racional da forma de apropriação do ambiente pelo homem, pois o estudo do relevo passa a ser uma abordagem fundamental no planejamento territorial, uma vez que estabelece categorias de avaliação conforme o grau de suscetibilidade ou fragilidade de cada ambiente, alertando sobre os problemas da influência antrópica. (MOURA, 2011, p. 174).

As aglomerações urbanas representam corpos complexos em processo de expansão espacial permanente. O relevo constitui a expressão física das condições de equilíbrio na litosfera, isto é, no substrato de todos os equipamentos implantados pelo ser humano. O preço pago pela inobservância das mínimas regras impostas pela natureza tem sido muito caro às populações e às administrações públicas. Além dos desastres ambientais, as consequências estenderam-se muitas vezes a perdas de vidas e de patrimônios.

Ao estudar a organização do relevo, a constituição geológica, suas formas de evolução e condições de equilíbrio, a geomorfologia permite estabelecer prognósticos sobre as potencialidades ofertadas ao uso urbano, bem como sobre as limitações impostas ao mesmo. Além disso, os agentes 
antrópicos devem ser inseridos, tratando-os como parte do sistema que proporciona alterações importantes na paisagem.

A compreensão dos fatores que definem os processos morfodinâmicos passa inclusive pelo conhecimento das intervenções antrópicas que, geralmente, estão associadas a corte e/ou aterros sobre a morfologia original, remanejando os materiais superficiais com o objetivo de obter superfícies de forma que possa receber incrementos topográficos por construções ou edificações.

Nesse sentido, a Geomorfologia contribui com o planejamento urbano quando define subsídios para o conhecimento do terreno onde está assentada uma cidade. Ao ter este levantamento é possível propor formas de ocupação urbana, proporcionando qualidade de vida àquela população.

\section{Planejamento Urbano e Impactos Socioambientais}

Analisar a distribuição populacional é fundamental para a elaboração de políticas sociais e econômicas pensadas numa perspectiva regional. Sob esse aspecto importa, sobretudo, compreender o lugar das metrópoles na rede urbana tendo em vista que esses espaços necessitam de políticas que sejam pensadas no seu conjunto. As políticas de saúde, mobilidade urbana, saneamento, dentre outras, requerem articulações entre os entes federativos inseridos nas metrópoles, visto que qualquer ação isolada de um desses entes federados, como os municípios, poderá haver consequências indesejadas para todo o território metropolitano.

Isso está diretamente ligado às mudanças populacionais nas metrópoles, que não se resumem apenas à saída de pessoas, até porque boa parte da emigração dos núcleos metropolitanos ocorre para municípios da própria periferia metropolitana, ou para municípios que apresentam forte relação com a dinâmica metropolitana. Conforme o Observatório das Metrópoles (2010), a metropolização pode ser pensada em termos de difusão do fenômeno metropolitano, que passa não apenas por contiguidade territorial, mas também por conectividade na economia em rede e por polarização econômica.

Na ordenação das aglomerações urbanas, usos e costumes são cada vez mais importantes, pois podem significar intenções morais e deveres de Estado, então abrangendo a gestão e a consciência do ato administrativo para as comunidades. Desse modo, as leis influenciam as ações individuais ou de grupos e também as coletividades urbanas, sejam nacionais ou em diferentes regiões do País.

No entanto, em oposição à estruturação dessas áreas macros, fortalecidas pelo setor terciário superior, inovações comerciais e habitações em condomínios, as áreas de ocupação precária e irregular continuam necessitando urgentemente de higiene e saúde ambiental. Normalmente, as 
habitações dessas áreas não acompanham os padrões propostos pela legislação urbanística e ambiental, existindo, quanto a essas condições, em situação informal, irregular ou clandestina.

Diante de situação como essas, cabe ressaltar que o desenvolvimento urbano é fundamentado na Lei Federal № 10.257/2001, o Estatuto da Cidade. Essa lei determina que os municípios cuidem de seu desenvolvimento e expansão urbana, constituindo sua própria política, a partir das diretrizes do Sistema Nacional de Desenvolvimento Urbano.

A baixa qualidade de vida nas cidades, sobretudo as metropolitanas, tem sido agravada ainda mais pela diversidade de formas de poluição resultantes especialmente da produção industrial e do sistema dominante de transporte por automóveis. Dentre muitos outros problemas socioambientais existentes nas cidades, também devem ser mencionados os serviços públicos ineficientes, a distribuição desigual de equipamentos urbanos e comunitários, a falta de áreas verdes, os padrões inadequados de uso do solo e a baixa qualidade técnica das construções.

Entretanto, o processo de metropolização tem sido uma das características mais importantes do crescimento urbano, e matérias ambientais fundamentais como abastecimento de água, transporte, localização industrial, aterros sanitários e uso do solo, dentre outras, têm uma dimensão metropolitana que não pode ser devidamente tratada somente a partir do nível municipal, apesar de que o planejamento urbano ocorre praticamente neste nível da federação, e não articulado com municípios vizinhos.

Um dos resultados dessa situação é que o fenômeno da ilegalidade tem sido causado não só pela combinação entre mercados de terras especulativos e sistemas políticos excludentes, mas também pela ordem jurídica em vigor. O lugar dos pobres nas cidades tem sido as áreas inadequadas para a ocupação humana e, com frequência cada vez maior, em áreas públicas e em áreas de preservação ambiental.

Não há como negar a estreita relação entre riscos urbanos e a questão do uso e ocupação do solo que, entre as questões determinantes das condições ambientais da cidade é aquela onde se delineiam os problemas ambientais de maior dificuldade de enfrentamento.

Com isso, a dinâmica da urbanização pela expansão de áreas suburbanas produziu um ambiente urbano segregado e altamente degradado, com efeitos muito graves sobre a qualidade de vida da população. Espaços inadequados para moradias foram ocupados. Condições precárias de habitações em favelas e loteamentos periféricos aumentam o déficit de infraestrutura urbana; suas localizações em áreas críticas de risco multiplicam as condições predatórias à urbanização existente e seu impacto de degradação ambiental. Conforme Mendonça (2010): 
Os problemas ambientais que ocorrem nas cidades são, por princípio, problemas socioambientais, pois a cidade é o mais claro exemplo de espaço onde a interação entre a Natureza e a Sociedade se concretizam. Nesta compreensão, torna-se impossível tratar dos problemas ambientais que ocorrem nos espaços urbanos, levando-se em consideração somente a natureza e os processos naturais. As cidades são bastantes diferentes umas das outras e, por conseguinte, também os problemas que as caracterizam; naquelas dos países pobres, ou em estágio de desenvolvimento complexo, eles são muito mais marcantes e expressivos que naquelas dos países ricos, do norte, ou desenvolvidos. (MENDONÇA, 2010, p. 204-205).

Tem-se hoje uma situação parodoxal, pois convivem uma enorme produção habitacional, um elevado déficit habitacional (quantitativo e qualitativo) e um significativo montante de habitações vazias nas áreas centrais e mais bem servidas da cidade. Aqueles que querem e precisam ali morar, não conseguem viabilizar o acesso às moradias disponíveis e buscam solução nos bairros precários e afastados dos serviços públicos.

Ao elencar elementos que dizem respeito ao planejamento urbano, com o objetivo de promover a qualidade de vida nas cidades, elucida-se que esse assunto está diretamente relacionado com as condições sociais e ambientais que respectivos municípios oferecem aos seus cidadãos. Os impactos socioambientais tendem a serem consequências de como são enfrentados os problemas urbanos, bem como a ordenação do território.

\section{PROCEDIMENTOS OPERACIONAIS}

\section{Bibliografia}

No intuito de conhecer a região onde se localiza o Município de Sapucaia do Sul e entender a sua dinâmica social e ambiental, foram identificadas e estudadas as bibliografias que abordam a geologia e a geomorfologia, tanto do Rio Grande do Sul, quanto da Região Metropolitana de Porto Alegre.

Foi possível pelas bibliografias e por mapas elaborados com esse objetivo, identificar o contexto geológico da região e, dessa forma, visualizar e explicar as formas de relevo mapeadas, como o trabalho de Andreis et al (1983), Argento (2003), Brasil (1986), Estado (2011a) e Suertegaray e Fujimoto (2004).

Para a elaboração do mapeamento geomorfológico, buscaram-se subsídios em outros trabalhos de graduação e de dissertação, como Dias (2011), Rehbein (2005) e Penteado (2006), que tiveram na sua essência a análise de expansões urbanas e ainda de formas de relevo em ambientes 
urbanos, assim como trabalhos de Florenzano (2008), Nunes e Rocha (2008), Ross (1992) e Ross e Fierz (2005).

A questão histórica do município é abordada para entender a dinâmica de ocupação da cidade. Além do Plano Diretor de 2006, onde foram elaborados diagnósticos sociais e ambientais, buscaram-se outros trabalhos da Prefeitura Municipal de Sapucaia do Sul, principalmente no que se refere aos planos setoriais (habitação, transporte e mobilidade, saneamento, etc.), uma vez que são, nestes trabalhos, identificados a dinâmica atual e histórica da cidade, além de estudos e publicações sobre a cidade, como Allgayer (1988; 1992), Gonçalves (2013) e Padilha (2000).

\section{Elaboração de mapas}

Para alcançar o objetivo principal, foi realizada a combinação das informações do mapa geomorfológico com a ocupação urbana. Para a mancha urbana na série histórica de 1930 a 2010, foi consultado o Plano Diretor de Sapucaia do Sul, onde já existia essa informação.

A partir do mapa geomorfológico, foram elaborados mapas representando três períodos históricos de Sapucaia do Sul, sendo eles: a ocupação até 1950, outro de 1980 e ainda o período atual, compreendendo até 2010, totalizando três mapas em que a informação representa a ocupação urbana sobre o relevo, visualizando a expansão urbana num período de oitenta anos. Na relação entre eles foi possível entender por quais compartimentos de relevo a expansão da cidade ocorreu em cada período e qual a porcentagem ocupada em cada forma de relevo, promovendo um crescimento da Zona Urbana.

Além disso, com dois mapas resultantes dessa combinação, um com a área ocupada no município e outro sem ocupação, procurou-se extrair deles os limites propostos pelos parâmetros ambientais, como declividade e hipsometria, entre outros. Dessa combinação surgiram dois mapas propositivos indicando quais áreas não poderiam estar ocupadas hoje, de acordo com os nove parâmetros ambientais e territoriais, e um outro mapa em que, em relação às áreas vazias, não poderá ser ocupada as zonas indicadas por conta da legislação vigente, tanto federal, estadual ou municipal.

\section{Trabalho de campo}

Durante a elaboração dos mapas e a redação do trabalho, foram realizadas saídas de campo no Município de Sapucaia do Sul.

Para o tratamento das informações nos mapas, conforme metodologia de Ross (1992), já empregada em trabalhos dessa natureza, foram checadas e corrigidas as informações dos mapas 
gerados em gabinete; buscou-se identificar os diferentes padrões, tipos e formas de relevo; realizaram-se registros fotográficos dos elementos observados; e analisaram-se as formas de relevo e a hidrografia para depois organizá-los em padrões de formas semelhantes. No intuito de identificar tendências de crescimento do município, foram visitados locais de vazios urbanos e regiões de expansão atual, identificados por mapas do Plano Diretor, avaliando as reais condições para futuros assentamentos em pequenas saídas de campo com alguma finalidade específica.

\section{Gabinete}

O trabalho em gabinete, além de dissertar sobre a pesquisa realizada, foi também a etapa de tratamento dos dados, elaboração dos mapas, bem como análise de estudos anteriores. Com as informações observadas e obtidas, tanto na utilização de softwares quanto de estereoscópio, essa etapa permitiu a organização e melhoramento dos dados, incluindo a elaboração de mapas, cujas informações do campo são ilustradas ao longo desse trabalho, sendo eles o de hipsometria, declividade e o geomorfológico.

Nessa etapa ocorreu a análise e interpretação de todo o material existente que viabilizou a construção do mapa geomorfológico - produto cartográfico de síntese com as seguintes informações: morfologia, morfometria, morfogênese e morfocronologia. A produção cartográfica teve como apoio a revisão bibliográfica e cartográfica, elaboração do mapa hipsométrico, declividade, interpretação de fotografias aéreas, elementos do relevo e das observações do campo, utilizando do software ArcGIS Map 10, trabalhando na escala 1:50.000.

Junto à Prefeitura Municipal de Sapucaia do Sul, pesquisou-se todo o arquivo da Secretaria Municipal de Planejamento Urbano com o intuito de identificar a evolução da ocupação urbana via os registros dos loteamentos na cidade, assim como a criação dos bairros. Algumas das plantas desses loteamentos ainda eram da época em que Sapucaia do Sul pertencia ao Município de São Leopoldo.

\section{RESULTADOS}

É um desafio para as cidades planejarem os seus futuros de acordo com as regras exigidas por lei e adaptando-as para as realidades e particularidades socioespaciais em cada território. Neste item abordar-se-á elementos que identificariam as possíveis áreas de ocupação urbana em Sapucaia do Sul de acordo com parâmetros estabelecidos em legislação federal, estadual e municipal, no intuito de fazer a população relacionar-se melhor com o meio ambiente urbano.

Nesse sentido, ao analisar os aspectos legais que regem as cidades, foi possível caracterizar com mais propriedades a evolução urbana no período proposto, tendo em vista que são a partir das 
leis, em suas mais variadas formas, abrangências e épocas, que partem as sínteses praticadas no território e na vida da população. Com isso, buscou-se exercitar as tendências de expansão aplicando a legislação vigente onde ainda não há uma efetiva ocupação em áreas mostradas por meio de mapas.

\section{Aspectos Legais}

Ao buscar a compreensão da legislação, tem-se por objeto a análise dos aspectos institucionais compreendidos pela legislação territorial e ambiental na esfera municipal, estadual e federal, visto que o produto do espaço geográfico também é induzido por instrumentos políticoinstitucionais, organizando espacialmente o território.

Sabe-se que, mesmo que haja regras previstas em leis para a devida ocupação do território, há duas situações cujo real cumprimento delas esbarra: a primeira seria a falta de regulamentação, causando o desuso de uma lei que nem chegara a ser implementada na prática, a exemplo de leis federais; a segunda seria a falta de fiscalização, indicando ainda uma ausência do poder público no que diz respeito à ocupação das cidades, originando assim loteamentos e ocupações irregulares, principalmente em áreas impróprias para a ocupação urbana, levando pessoas às vulnerabilidades e aos riscos ambientais.

Neste sentido, deve ser estabelecida uma relação entre a legislação, enquanto instrumento governamental de ordenamento do uso da terra, em contraposição à realidade da dinâmica do meio físico e da dinâmica da sociedade. Com base nisso, foram consultadas as seguintes leis para cumprir os objetivos:

1. Lei Federal № 6.766, de 19 de dezembro de 1979: dispõe sobre o Parcelamento do Solo Urbano e dá outras providências. Conhecida como Lei de Loteamentos;

2. Lei Federal № 10.257, de 10 de julho de 2001: estabelece diretrizes gerais da política urbana e dá outras providências. Conhecida como Estatuto da Cidade;

3. Lei Federal № 12.651, de 25 de maio de 2012: estabelece normas gerais sobre a proteção da vegetação, áreas de Preservação Permanente e as áreas de Reserva Legal; a exploração florestal, o suprimento de matéria-prima florestal, o controle da origem dos produtos florestais e o controle e prevenção dos incêndios florestais, e prevê instrumentos econômicos e financeiros para o alcance de seus objetivos. Conhecida como Novo Código Florestal;

4. Lei Estadual № 9.519, de 21 de janeiro de 1992: institui o Código Florestal do Estado do Rio Grande do Sul e dá outras providências;

5. Lei Estadual № 11.520, de 03 de agosto de 2000: institui o Código Estadual do Meio Ambiente do Estado do Rio Grande do Sul e dá outras providências; 
6. Lei Municipal № 2.896, de 11 de outubro de 2006: institui o Plano Diretor, suas diretrizes, adequando-o ao Estatuto das Cidades e dá outras providências para orientação e controle da cidade. Elenca como princípios do Plano Diretor e da política de desenvolvimento e gestão territorial e urbana do Município de Sapucaia do Sul, o direito à cidade sustentável, a função social da cidade, a função social da propriedade e a gestão democrática.

As leis federais regem principalmente a dinâmica de cidades maiores, pelo menos aquelas com população com mais de vinte mil habitantes, como é o caso do Estatuto da Cidade, quando obriga os municípios com uma quantidade maior do que essa ou ainda que estejam em regiões metropolitanas que elaborem os seus planos diretores.

Conforme quadro 1, foi nas legislações federais que se encontraram os índices legais para os seguintes parâmetros: declividade, altitude, distância de cursos d'água, distância de rodovias, distância de áreas de drenagem e distância de lagos.

Quadro 1 - A Legislação, os Índices e os Parâmetros

\begin{tabular}{|c|c|c|c|}
\hline \multicolumn{2}{|r|}{ Parâmetro } & Índice & Referência Legal \\
\hline 1 & Declividade & $30 \%$ & Lei Federal № 6.766/1979 \\
\hline 2 & Altitude & $\begin{array}{l}\text { Até } 2 / 3 \text { da altura } \\
\text { mínima da base }\end{array}$ & Lei Federal № 12.651/2012 \\
\hline 3 & $\begin{array}{c}\text { Distância de cursos } \\
\text { d'água }\end{array}$ & 30 metros & $\begin{array}{l}\text { Lei Federal № } 12.651 / 2012 \text { e Lei Municipal } \\
\text { № } 2.896 / 2006\end{array}$ \\
\hline 4 & $\begin{array}{l}\text { Distância de áreas de } \\
\text { preservação }\end{array}$ & 26 metros & Lei Municipal № 2.896/2006 \\
\hline 5 & Distância de rodovias & 15 metros & Lei Federal № 6.766/1979 \\
\hline 6 & $\begin{array}{l}\text { Distância de áreas de } \\
\text { drenagem }\end{array}$ & 30 metros & Lei Federal № 12.651/2012 \\
\hline 7 & $\begin{array}{l}\text { Distância do rio dos } \\
\qquad \text { Sinos }\end{array}$ & 100 metros & Lei Municipal № 2.896/2006 \\
\hline 8 & Distância de lagos & 30 metros & Lei Federal № 12.651/2012 \\
\hline 9 & $\begin{array}{l}\text { Zoneamentos do Plano } \\
\text { Diretor }\end{array}$ & $\begin{array}{l}\text { Conforme região } \\
\text { analisada }\end{array}$ & Lei Municipal № 2.896/2006 \\
\hline
\end{tabular}

Elaboração: os autores.

Já as leis estaduais, como o Código Florestal do Estado do Rio Grande do Sul e o Código Estadual do Meio Ambiente, servem de parâmetros e diretrizes para os municípios gaúchos na composição de suas legislações ambientais. No entanto, os parâmetros adotados para este trabalho não constam nas leis estaduais, utilizando, assim, as leis nacionais e municipal.

No que tange às leis municipais, o Plano Diretor de Sapucaia do Sul, após alguns anos de tentativa de aprovação na Câmara Municipal de Vereadores, ganhou fôlego com o Estatuto da Cidade e estabeleceu como estratégias para a política urbana e organização territorial do município: o planejamento e gestão urbana, desenvolvimento socioeconômico, saneamento ambiental, 
desenvolvimento habitacional, mobilidade urbana e acessibilidade e a preservação do patrimônio ambiental e cultural.

O Plano Diretor institui ainda o macrozoneamento territorial, formado por quatro áreas territoriais distintas, consideradas na identificação de possíveis áreas de ocupação, conforme seguem:

1. Zona Mista: como área intensiva de ocupação, densificação e indução do crescimento e desenvolvimento urbano de áreas consolidadas e em consolidação;

2. Zona Rural, com característica de ocupação rarefeita como área extensiva, onde as diretrizes de uso e ocupação devem promover prioritariamente as atividades agroindustriais, agroecológicas e de turismo sustentável;

3. Zona Industrial: com característica de ocupação industrial, com acessibilidade proporcionada pelo sistema viário do entorno principal;

4. Zonas de Interesse ambiental: definidas em função das necessidades de proteção integral e dos diferentes graus de uso sustentável permitidos são compostas por ecossistemas de interesse para a preservação, conservação e desenvolvimento de atividades sustentáveis.

O zoneamento, de acordo com o mapa 1, se constitui na subdivisão da Zona Mista (área urbana), segundo características locais, quanto aos aspectos de identidade, expectativa de densificação, ambientais e de ocupação e uso, Zona Industrial, Zona de Interesse Ambiental e Zona Rural, conforme segue: Zona de Interesse Ambiental; Zona Industrial; Zona Mista Central; Zona Rural; Corredores de Comércio e Serviço Principais e Secundários; Corredor Industrial.

No espaço urbano, as Zonas de Interesse Ambiental 1, 2 e 3 abrangem área significativa da cidade. Estão próximas ao rio dos Sinos e à Zona Rural, e em parte, ao lado da BR-116.

A Zona Industrial, ao longo da BR-116 e ERS-118, destina-se à localização de empresas de grande porte, aquelas que requerem localização afastada do uso residencial. 
Zoneamento Urbano de Sapucaia do Sul - RS.

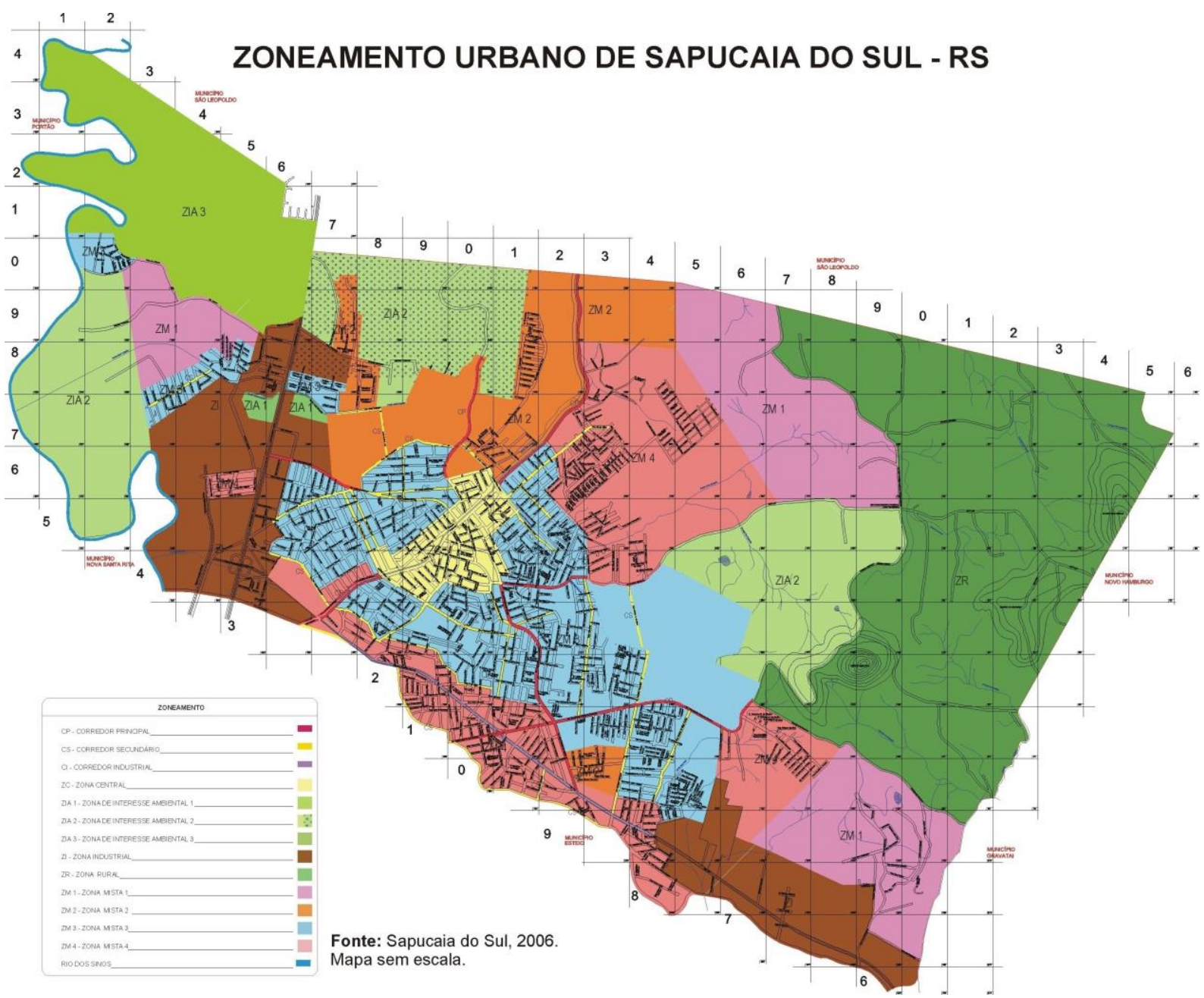

Fonte: Sapucaia do Sul, 2006.

Os Corredores Principal e Secundário são para uso comercial, serviços e residencial com maiores densidades e compatíveis com o fluxo de trânsito e transporte existente, sendo definidos, para ambos, parâmetros urbanísticos próprios. Já o Corredor Industrial é para predominância de uso industrial e para instalação de indústrias de até grande porte do tipo incômodas ou perigosas.

Incluída na Zona Mista, a Zona Central tem como característica a predominância de uso misto com ênfase ao uso de comércio e serviços e residencial multifamiliar.

O Plano Diretor de Sapucaia do Sul ainda apresenta, no Título VII, Instrumentos JurídicoUrbanísticos da Política Urbana, Capítulo I as Zonas Especiais de Interesse Social, conceituadas como "porções do território onde deverá ser promovida a regularização urbanística e fundiária dos assentamentos habitacionais de baixa renda existentes e consolidados e o desenvolvimento de 
programas habitacionais de interesse social nas áreas não utilizadas ou subutilizadas". São classificadas como:

1. ZEIS 1 - áreas públicas ou baixa renda, significativamente precários do ponto de vista urbanístico e habitacional, predominantemente localizados em encostas com altas declividades, com acessibilidade inadequada, riscos com atendimento parcial das demandas por infraestrutura, serviços urbanos e equipamentos comunitários ou sem atendimento nenhum

2. ZEIS 2 - imóveis públicos ou particulares edificados ou não, não utilizados, dotados parcialmente de infraestrutura e serviços urbanos, necessários à implantação de HIS, com respectivos equipamentos comunitários e urbanização complementar adequados, que serão objeto de parcelamento, edificação ou utilização compulsório.

A partir das regras estabelecidas pelo Plano Diretor do município, somado às regras gerais das leis federais e estaduais, definiu-se os parâmetros apresentados no quadro 1 que nortearam a elaboração do mapa de tendências de ocupação, conjuntamente com seus respectivos índices e a referência legal estabelecida juridicamente.

Com os parâmetros tratados no quadro anterior, tem-se o intuito de justificar e de trazer os parâmetros legais para a devida discussão, não só neste estudo, mas também no ambiente público e junto à sociedade civil.

Nesse sentido, a questão territorial assume um papel importante. Políticas tradicionais de produção de casas de forma descolada do contexto urbano, que não consideram a sua localização, a oferta de serviços e de infraestrutura, produziram problemas sociais graves em muitas cidades brasileiras, problemas que hoje agravam o quadro do déficit habitacional brasileiro e das situações de inadequação habitacional.

\section{Caracterização e Evolução Urbana de Sapucaia do Sul}

Sapucaia do Sul cresce e se urbaniza inserida no processo de expansão de desenvolvimento metropolitano. Na década de 1960, outros centros industriais, além dos já consolidados (Porto Alegre, Novo Hamburgo e São Leopoldo), começam a se destacar. Canoas disputa posição com Novo Hamburgo, e Sapucaia do Sul e Esteio com menor peso.

A figura 2 é uma visualização do que aconteceu em Sapucaia do Sul, cujo município é a área de estudo deste trabalho, sendo a dinâmica semelhante em municípios da região e do país. Ao lado esquerdo da figura uma imagem provavelmente de 1940, segundo Allgayer (1992). À direita uma imagem recente. 
À esquerda uma imagem de Sapucaia do Sul, provavelmente da década de 1940. À direita, e mesma feição da paisagem, no entanto com a ocupação urbana em setembro de 2012.

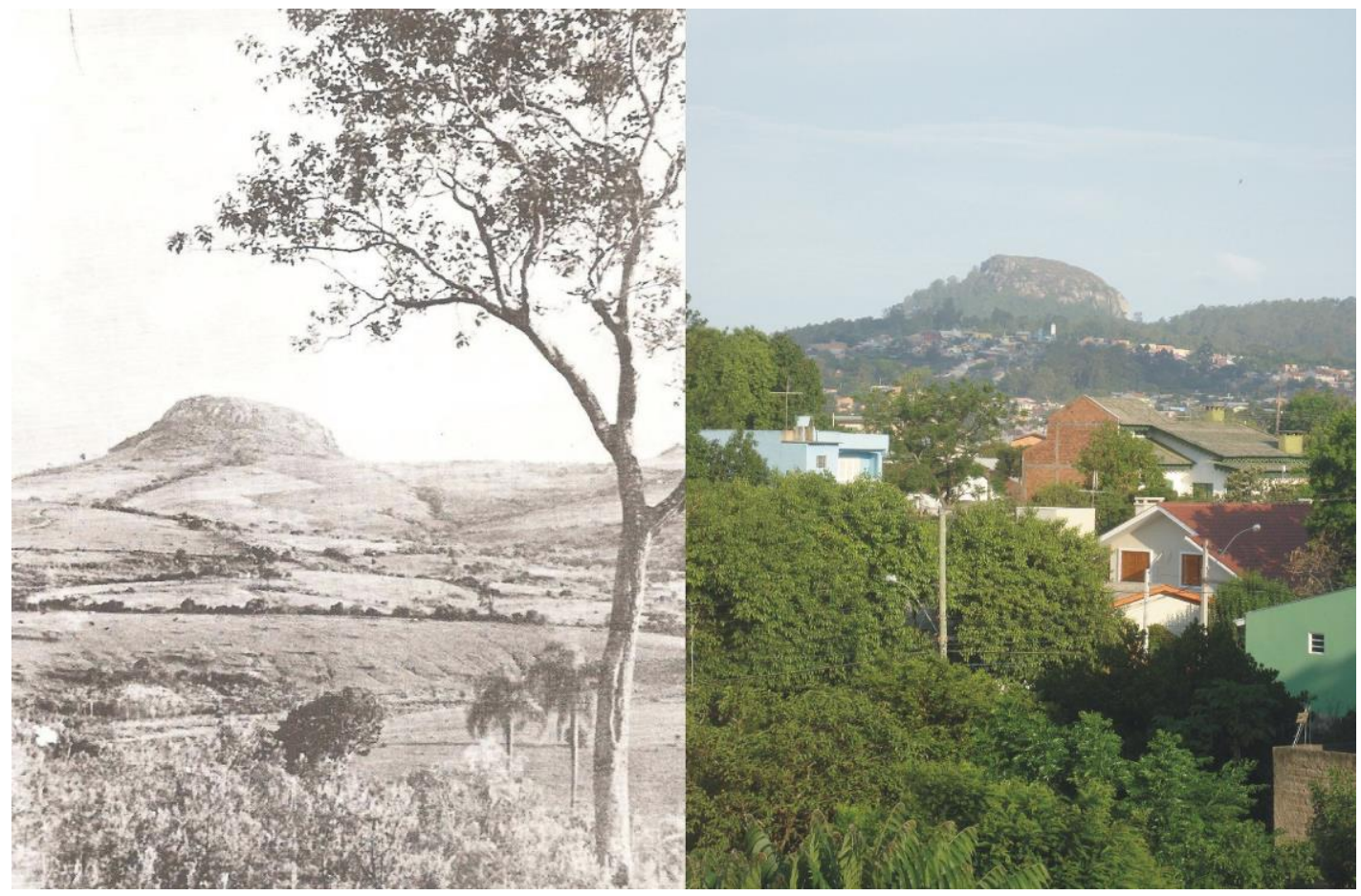

Fonte: Allgayer, 1992. Fotografia: os autores.

A paisagem alterada com o crescimento das cidades transforma a dinâmica e os usos do solo, que hoje é urbano. Os mapas 2, 3 e 4 identifica a evolução urbana em Sapucaia do Sul juntamente com a geomorfologia local.

Inicialmente, como mostra o mapa 2, é possível identificar que, até 1950 os loteamentos seguiram a estrutura do relevo, não ocupando as áreas de morro. Lembrando que nesta época, Sapucaia era apenas um distrito do Município de São Leopoldo, cuja administração buscava um ordenamento territorial adequado. 
Usos e ocupação urbana sobre o relevo - 1950.

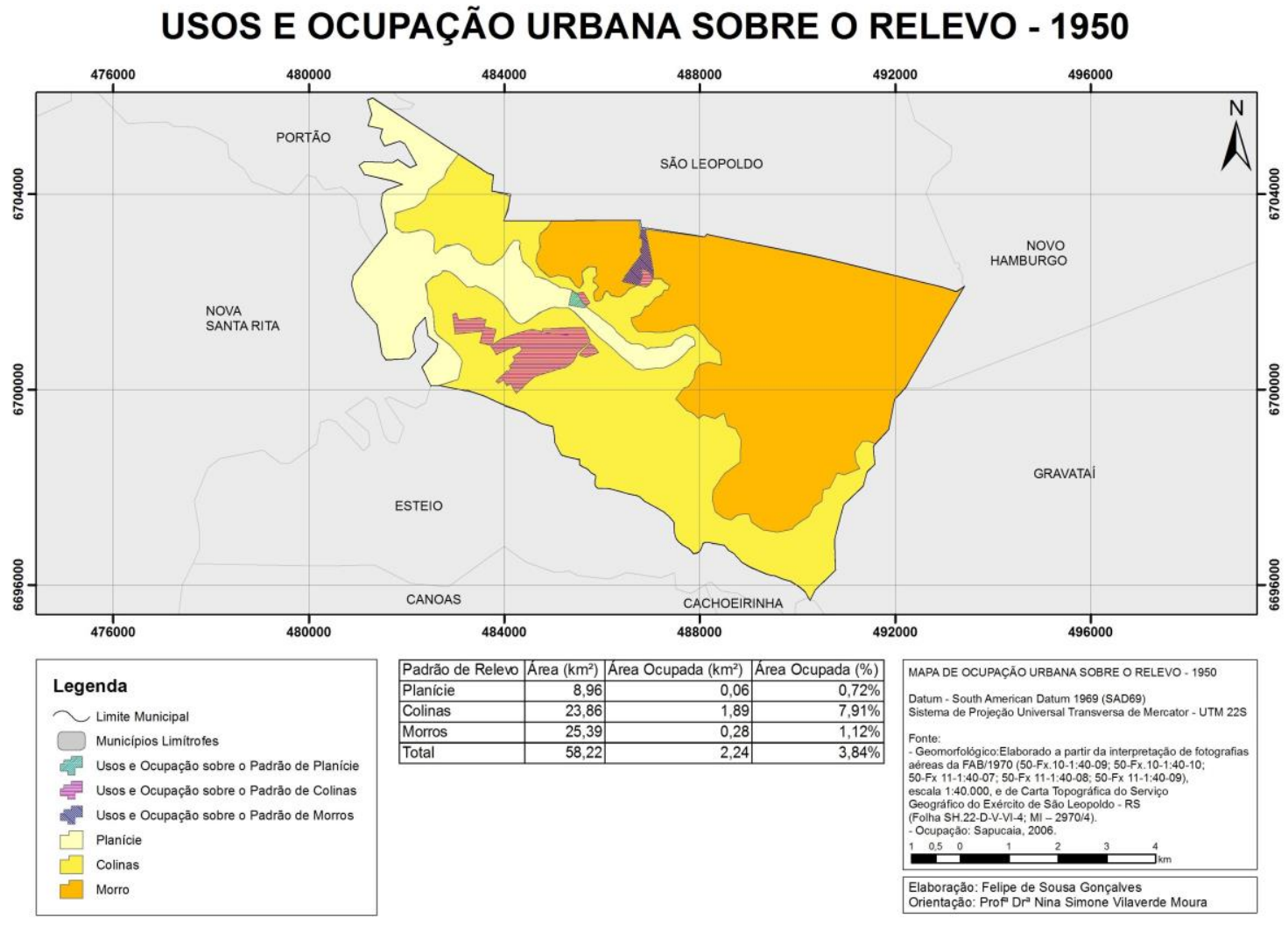

Elaboração: os autores.

Ao todo, nesse ano, o território que seria Sapucaia do Sul estava apenas 3,84\% ocupado. Além disso, o relevo que estava com alguma ocupação era as colinas, com 7,91\%. A vegetação, nesta época, como mostrou a figura 2, era composta de gramíneas, aparecendo algumas vegetações mais lenhosas em linhas de drenagem. A ocupação na região era rarefeita e onde hoje é Sapucaia do Sul o início se deu a partir de um núcleo que era a Estação Sapucaia da época.

Em 1980 os loteamentos são implantados em direção ao rio dos Sinos e à região oeste da cidade, ensaiando uma pequena ocupação das áreas de morro, como mostra o mapa 3. Mesmo que o crescimento tenha acontecido a partir de áreas já ocupadas, alguns outros pontos na cidade receberam loteamentos que induziram as vias urbanas, como na área do Bairro Carioca, onde havia fluxo em direção a uma praia no rio dos Sinos, ou ainda nas margens de rodovias, como o caso da ERS118. 
Usos e ocupação urbana sobre o relevo - 1980.

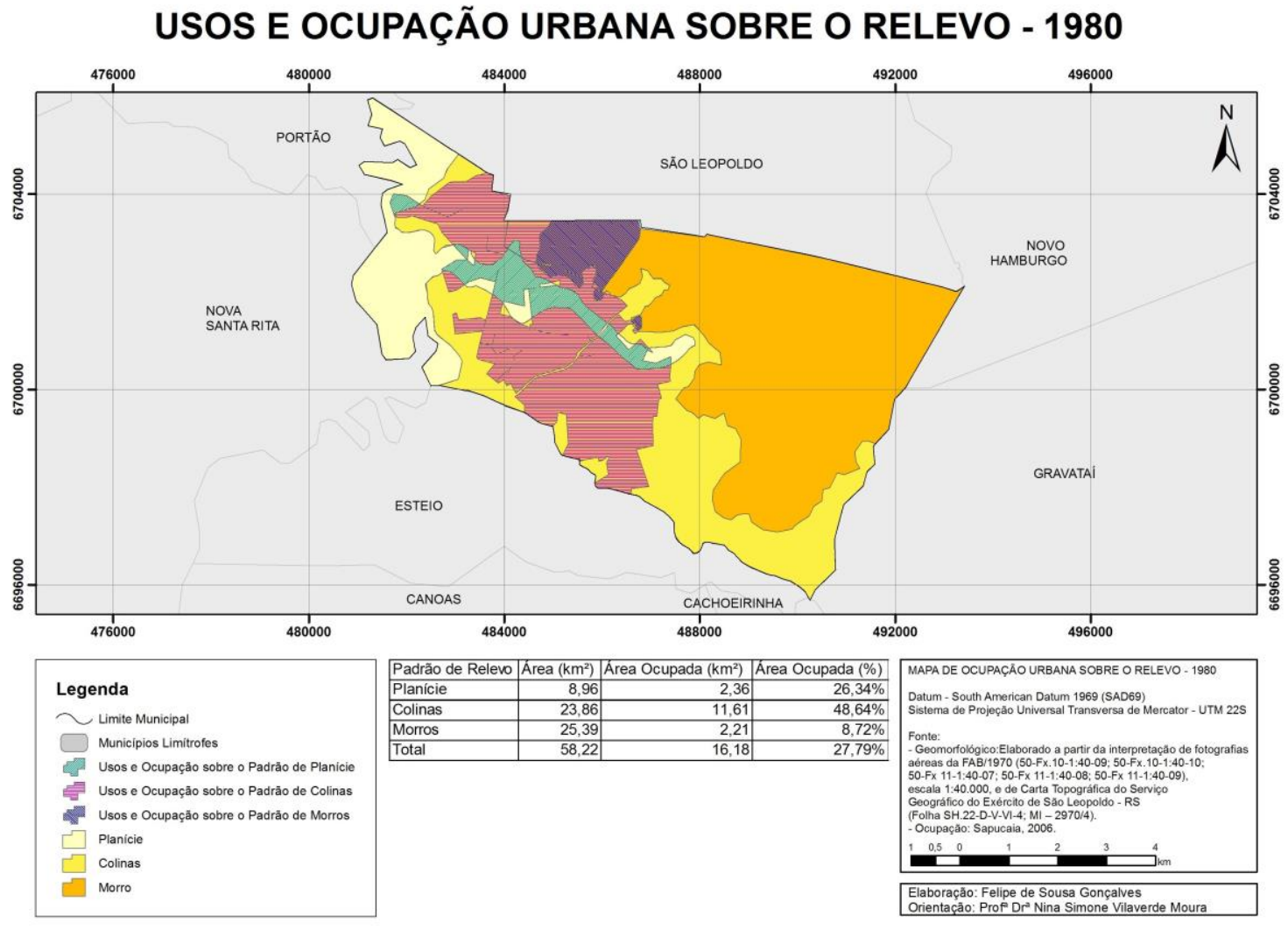

Elaboração: os autores.

Ainda assim, conforme o mapa 2, as planícies aumentaram a sua ocupação de 0,72\% para 26,34\% e as colinas de 7,91\% para 48,64\%, aumentos bastante consideráveis, tendo em vista o crescimento da cidade a partir da década de 1970.

Nesse período, os campos que haviam na cidade foram loteados, preservando as áreas de morros. O grande problema, no entanto, foram as ocupações junto aos cursos d'água. Tendo em vista que as vegetações arbóreas estavam concentradas em linhas de drenagem, esse tipo de vegetação foi prejudicado durante a ocupação. Além disso, iniciou-se um processo de mineração de argila e de arenito junto aos morros do município, iniciando outra atividade econômica.

Todavia é em 2010 que se nota quanto as áreas urbanas se tornaram homogêneas, chegando a ocupar a região de morros da cidade, conforme o mapa 4. Com isso, depois de duas reduções da Zona Rural, inicia-se uma nova ocupação naquela área. Mesmo assim, com a redução da área rural, a área total ocupada alcançou 52,13\%. A planície chegou a 33,88\% de ocupação, as colinas alcançaram a maior ocupação da cidade, com $81,20 \%$ e os morros $31,25 \%$ ocupado. 
Usos e ocupação urbana sobre o relevo - 2010.

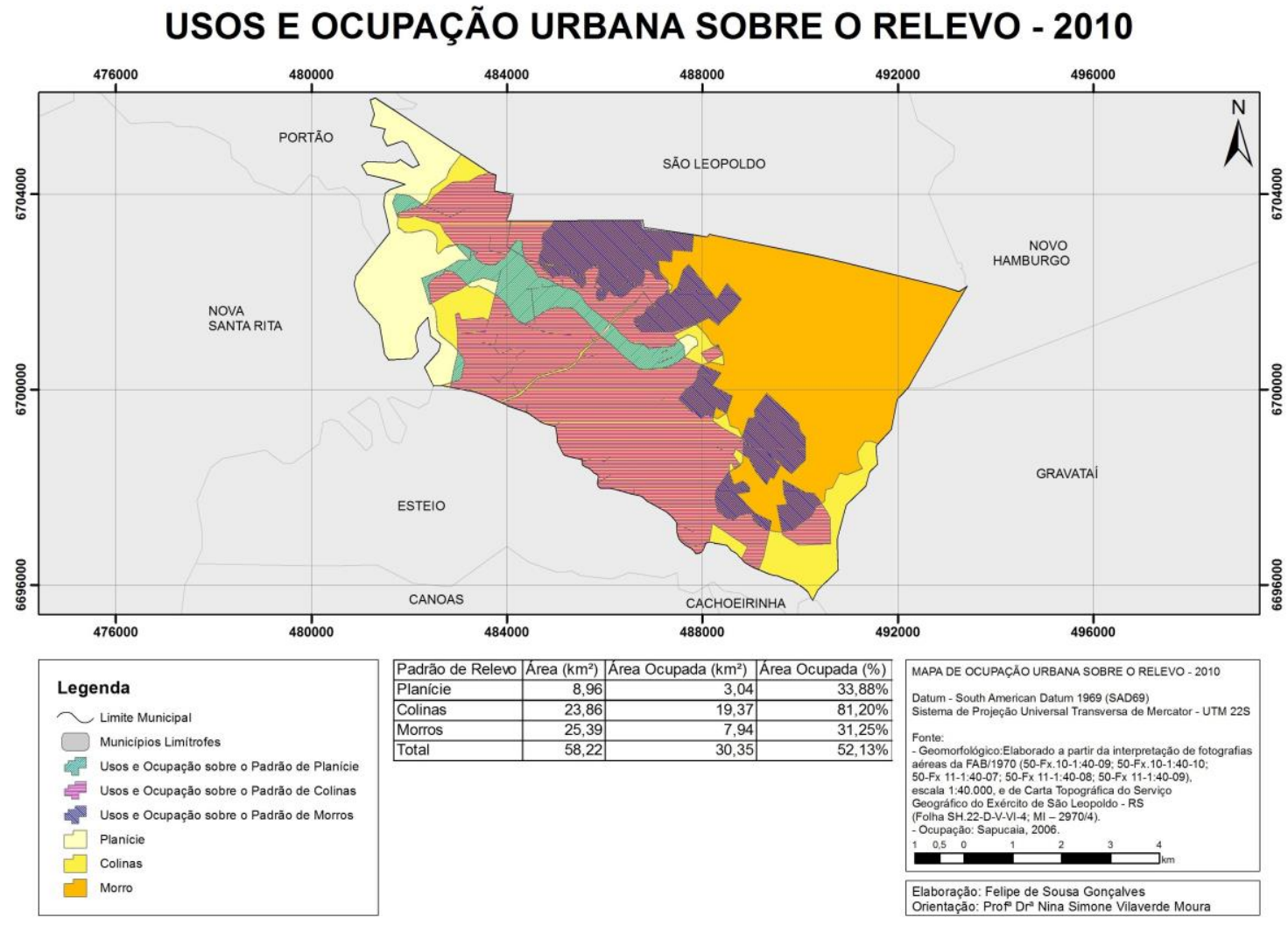

Elaboração: os autores.

Na zona oeste do município, uma das últimas áreas ocupadas, o Bairro Carioca, divisa com o Município de Portão, noroeste de Sapucaia do Sul, tem características de um vilarejo distante da dinâmica frenética de uma região metropolitana, cuja tempo passa a velocidade de uma balsa: vagarosa e calma. No Bairro Fortuna, região sudoeste de Sapucaia do Sul e divisa com o Município de Nova Santa Rita, a situação de miséria é ainda mais grave. No local conhecido como "fundos da Formigueiro", em alusão à última rua do bairro, há quantidades enormes de materiais recicláveis que são coletados na cidade com o auxílio de carroças. Se a miséria existe em Sapucaia do Sul, ela está neste lugar. Assim como inúmeros outros lugares do Brasil, diferentes realidades convivem lado a lado; esse local faz divisa com a Gerdau, uma das maiores empresas do estado e do país.

Em 2010 há uma heterogeneidade de atividades que compõe o território de Sapucaia do Sul, sendo que, inúmeras delas estão nas colinas, quando se tratam de moradias, indústrias, áreas de preservação ou mineração junto à área de morros do município. Nas áreas onde ainda não há ocupação, a vegetação campestre ainda é conservada. 
Como grande parte da cidade está assentada no Padrão em Formas de Colinas, não existem grandes problemas ambientais que possam oferecer risco à população. Salvo possíveis eventos de alagamentos ocorridos principalmente pelo arroio José Joaquim antes das obras de canalização, eventos como movimentos de massa tem pequenas chances de ocorrer, tendo em vista que apenas $1 \%$ do território tem declividade maior do que $30 \%$ e as maiores altitudes estarem relacionadas aos morros.

Contudo, segundo as legislações já abordadas, há parâmetros que devem ser respeitados e que podem ser cruciais em um determinado evento extremo que possa ocorrer. Com inúmeras moradias assentadas junto ao leito dos arroios no município, sua vulnerabilidade em Sapucaia do Sul é muito maior do que quaisquer outras localidades.

O mapa 5 faz um exercício de identificar quais áreas onde hoje já estão ocupadas e que não deveriam assim estar, levando-se em conta a legislação vigente, mesmo sabendo que algumas dessas regiões tenham sido ocupadas anteriormente à vigência das respectivas leis.

Áreas ocupadas com e sem restrições em Sapucaia do Sul.

\section{ÁREAS OCUPADAS COM E SEM RESTRIÇÕES EM SAPUCAIA DO SUL - RS}
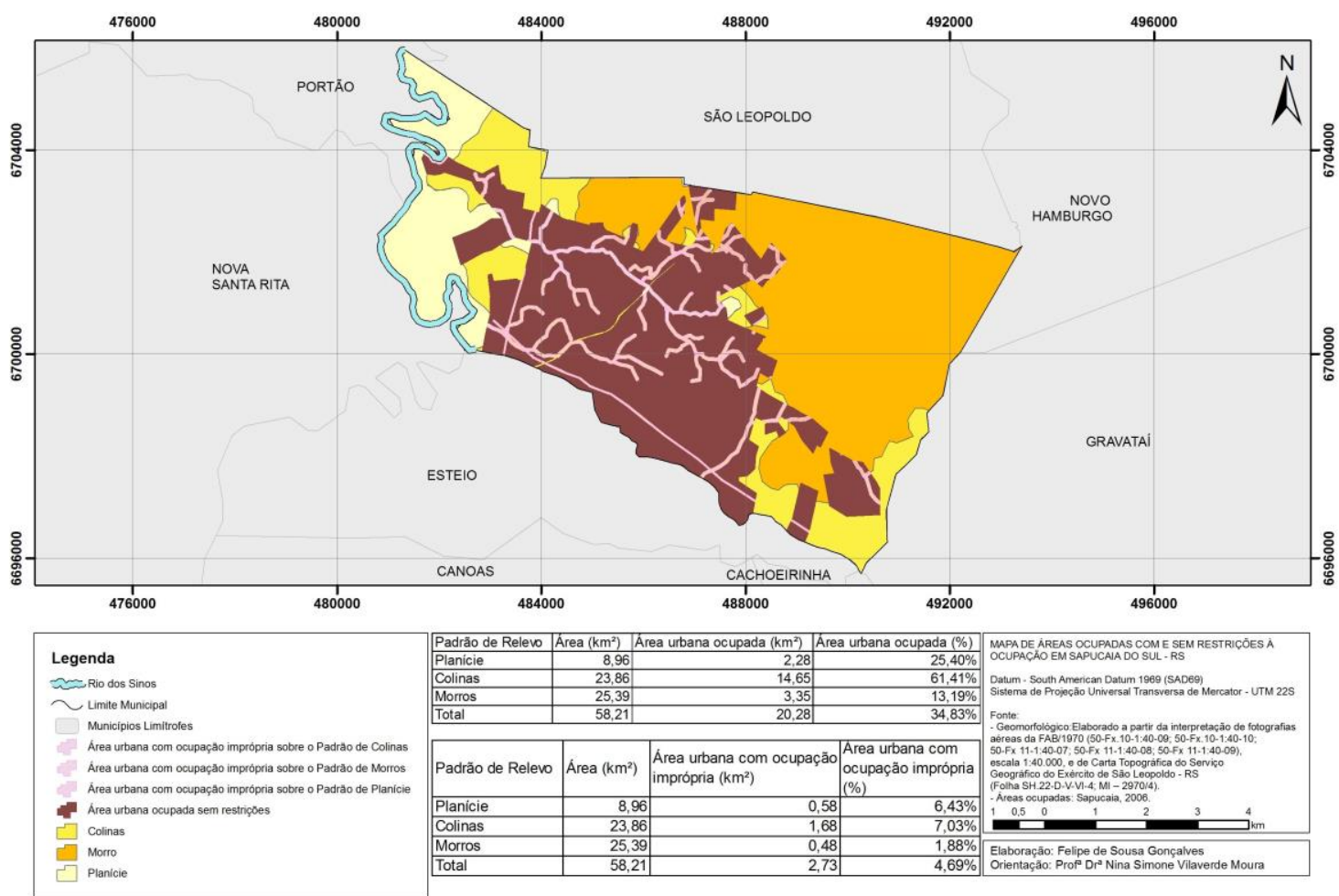

Elaboração: os autores. 
Nas áreas onde já existem loteamentos urbanos, o principal problema que ocorre são os alagamentos. Tendo em vista isso, é importante destacar que apenas três arroios banham essas áreas: o José Joaquim, Mem de Sá e o São Jorge.

Entretanto, o mais problemático era o arroio José Joaquim, que recentemente recebeu obras de canalização. Mesmo que a canalização aumente a velocidade de escoamento de um curso d'água, é possível que tais alagamentos não mais ocorram devido à limpeza e dragagem desses canais, além da remoção das famílias que viviam praticamente dentro do arroio.

Em relação ao arroio São Jorge, os problemas estavam relacionados com o arroio José Joaquim, uma vez que o seu exutório encontrava-se exatamente no ponto de maior incidência de problemas do José Joaquim. Antes de encontrar esse arroio, o São Jorge está canalizado e à montante dessa parte está dentro de uma área institucional vinculada ao Exército Brasileiro, teoricamente preservado.

O arroio Mem de Sá está quase na sua totalidade fechado. Tendo em vista algumas ocupações irregulares junto à ERS-118, é possível afirmar que esse arroio passa abaixo de moradias. Além disso, foi bastante difícil identificar o curso natural dele, já que a sua canalização data de pelo menos desde a Década de 1970. Segundo informações desse período já relatadas nesse artigo, essa época foi justamente quando ocorreu o inchaço urbano de Sapucaia do Sul.

Outros pontos críticos de alagamentos são as comunidades ribeirinhas ao rio dos Sinos. São pelo menos dois pontos que são recorrentes em alagamentos: bairros Carioca e Fortuna; pontos esses em que a vulnerabilidade social é bastante crítica.

Tendo em vista ainda as características das áreas compreendidas pelo Padrão em Forma de Morros, onde ainda há poucos loteamentos urbanos (por ser Zona Rural, sujeita a alterações na ocupação, com a consequente elevação do grau de urbanização), alguns problemas serão inseridos na região como consequência dessa nova condição.

\section{Tendências de crescimento em Sapucaia do Sul}

Partindo-se para uma escala intraurbana, percebe-se que a distribuição da população e de domicílios não ocorreu de forma uniforme no território urbano. A análise desta distribuição aponta indícios que ajudam a compreender o processo de urbanização recente, sendo possível traçar as tendências trazidas pelo quadro 2 .

Acredita-se que Sapucaia do Sul, em relação à sua população, já cresceu o que havia de crescer em toda a sua história. E não poderia ser diferente, visto que este é um comportamento 
nacional, e, sobretudo, gaúcho. Agora se inicia um período de rearranjo espacial dentro do município, levando a outra configuração urbana.

A diminuição da migração para Sapucaia do Sul e a possível criação de novas rodovias que passarão pelo município, induz a uma nova geografia na cidade, expandindo a cidade para outras áreas do território municipal, sem que haja grandes aportes populacionais.

Computando-se a área dos vazios urbanos para as quatro faixas de dimensionamento de áreas, chega-se a um total de aproximadamente $15 \mathrm{~km}^{2}$. Também se deve considerar que todas essas áreas se localizam em zoneamento apropriado ao uso habitacional, o que não significa que não possa haver condicionantes locais, que mostrem que alguns terrenos são inadequados para essa finalidade. Outra questão refere-se ao território urbano lindeiro à área rural, onde certamente existam glebas de terra cadastradas ainda como áreas rurais. Através de cadastros de lotes que pagam imposto territorial, disponibilizados pela administração municipal foi possível identificar por bairros, excluídos o zoneamento industrial e de interesse ambiental, vazios urbanos selecionados por seu dimensionamento.

Tendências de expansão em Sapucaia do Sul.

\begin{tabular}{|l|l|l|}
\hline Tendências de Expansão \\
\hline Funções & \begin{tabular}{l} 
Ênfase à industrialização. \\
\hline Outras regiões
\end{tabular} & $\begin{array}{l}\text { Expansão urbana; } \\
\text { Apoio à política habitacional e regularização fundiária; } \\
\text { Melhoramento das vias de acesso. }\end{array}$ \\
\hline & CIDADE & REGIÃO \\
\hline $\begin{array}{l}\text { Fatores } \\
\text { Populacionais }\end{array}$ & Diminuição do ritmo das imigrações. & $\begin{array}{l}\text { Desenvolvimento de cidades } \\
\text { de porte médio. }\end{array}$ \\
\hline $\begin{array}{l}\text { Fatores } \\
\text { Econômicos }\end{array}$ & $\begin{array}{l}\text { Indústria como economia mais importante; } \\
\text { Desenvolvimento do setor de serviços; } \\
\text { Facilidade de acesso, atraindo investimentos; } \\
\text { Fixação do comércio de maior monta. }\end{array}$ & $\begin{array}{l}\text { Setor primário: continuando } \\
\text { pouco expressivo; } \\
\text { Setor secundário: continua } \\
\text { crescendo; } \\
\text { Setor terciário: criação de } \\
\text { centros regionais. }\end{array}$ \\
\hline $\begin{array}{l}\text { Fatores } \\
\text { Locacionais }\end{array}$ & $\begin{array}{l}\text { Boa acessibilidade pela duplicação da ERS-118 e } \\
\text { vias alternativas a BR-116; } \\
\text { Melhoria na infraestrutura urbana. }\end{array}$ & $\begin{array}{l}\text { Implantação das rodovias BR- } \\
448 \text { e ERS-010. }\end{array}$ \\
\hline
\end{tabular}

Fonte: Sapucaia do Sul, 2006. Elaboração: os autores.

Vazios urbanos são áreas urbanas, seja ela uma gleba ou lotes isolados, que se localizam em áreas dotadas de infraestrutura urbana, e se encontram vazias ou subutilizadas. Os vazios urbanos em Sapucaia do Sul estão localizados em praticamente todos os bairros, constituindo-se numa reserva de 
áreas para lotear ou ocupar de acordo com a finalidade a que cada uma se destina para cumprir sua função social.

Segundo as informações espacializadas pelo mapa 6, é possível ver que ainda há áreas para uma expansão adequada somente junto ao limite da Zona Rural. No entanto, mesmo que haja limitações nessa Zona, deve-se considerar a implantação de uma nova rodovia na região, o que, em teoria, poderia provocar outra dinâmica social e econômica para essa área do município.

Áreas aptas à ocupação - Sapucaia do Sul - RS.

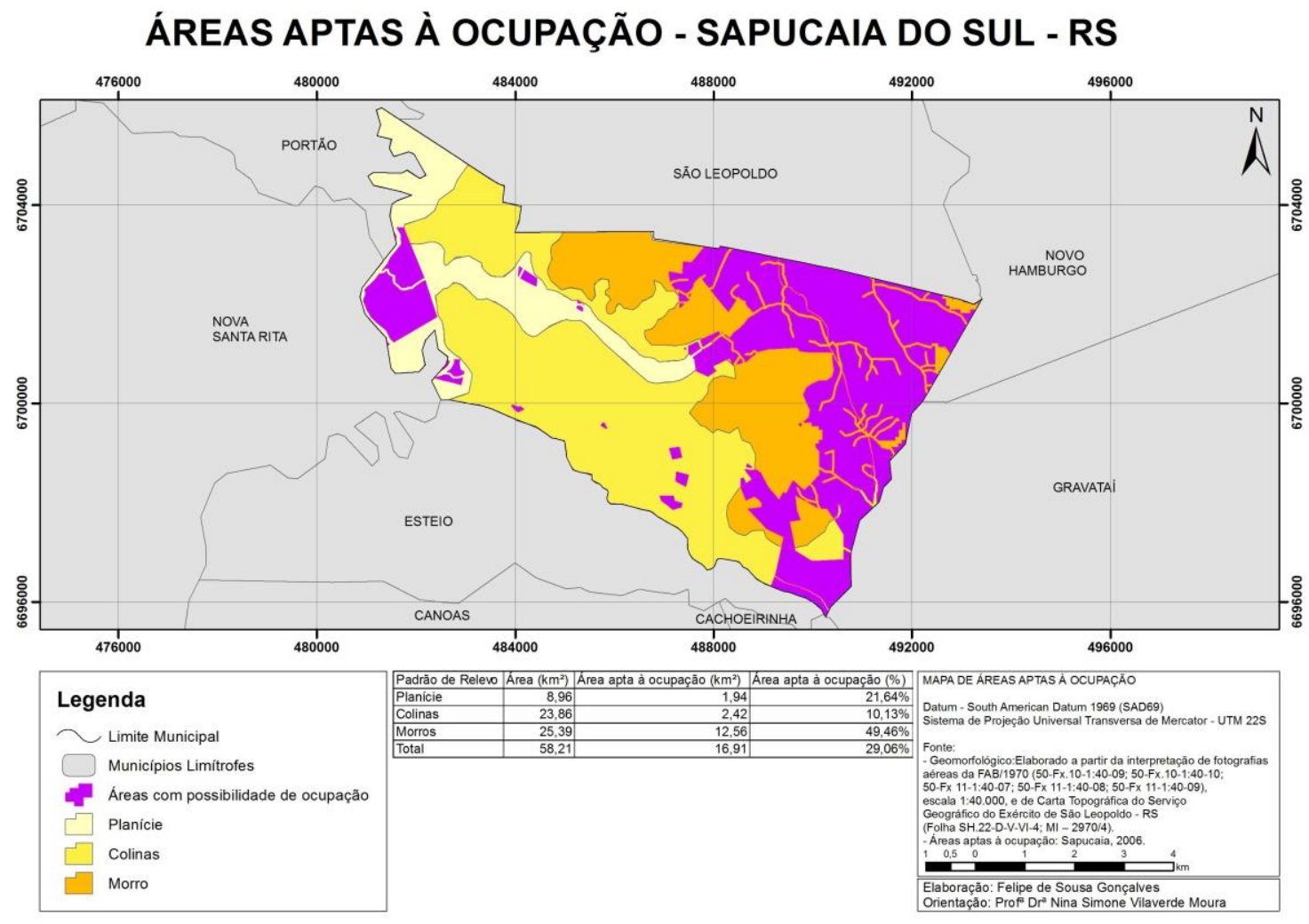

Elaboração: os autores.

O mapa indica as áreas aptas à ocupação urbana em Sapucaia do Sul, alcançando um índice de 29,06\% de todo o território. Com esse mapa identifica-se inclusive o quanto cada padrão de relevo está apto a ser ocupado. Diante do fato de que grande parte do que hoje é a cidade estar assentada sobre as colinas, o mapa mostra que apenas 10,13\% desse relevo está apto a ser ocupado, sendo que parte deles são vazios urbanos.

Evidentemente que, mesmo a planície tendo ainda 21,64\% de área a ser ocupada, são as áreas de morro que tem um grande potencial de ocupação, alcançando um índice de 49,46\%. Dessas áreas, 
foram retiradas as áreas equivalentes aos parâmetros estabelecidos no quadro 1 , bem como a inserção do traçado da nova rodovia estadual, que passaria pela Zona Rural. Com isso, o mapa mostra dois cenários possíveis para serem ocupados, respeitando ou não a Zona Rural. Como essa área está junto aos morros, a ocupação urbana terá que ser muito bem planejada para adequar os loteamentos às limitações físicas do relevo e da hidrografia.

Além disso, na região oeste do município, percebe-se que há muito mais limitações ambientais do que no lado oposto da cidade. Isso porque a pressão do rio dos Sinos junto com os arroios Mem de Sá e José Joaquim, levaram o Plano Diretor reservar essas áreas como de interesse ambiental, na tentativa de preservar aquilo que ainda não está ocupado. Junto à Zona Rural também constam áreas protegidas que, no entanto, não consideraram os parâmetros estabelecidos por este artigo no quadro 1 e trazidos no mapa.

O quadro 3 demonstra um resumo daquilo que resultou dos mapas. De acordo as áreas compreendidas com cada padrão de relevo, seguindo a metodologia de cada mapa, foi possível identificar como cada padrão desse relevo comporta-se frente a algum parâmetro de estudo. Ainda assim, percebe-se que, de onde a cidade está assentada hoje, apenas 4,69\% pode ser considerado inadequado. Parece ser pouco. Ao avaliar as condições de áreas com possibilidade de ocupação, identifica-se que $29,06 \%$ do total do município pode ser utilizado para fins de loteamentos, com destaque para as áreas de Morro, que alcançam um índice de 49,46\%.

Quadro 3 - Quadro demonstrativo com os índices resultantes dos mapas de relevo de Sapucaia do Sul.

\begin{tabular}{|c|c|c|c|c|c|c|c|}
\hline \multicolumn{2}{|c|}{$\begin{array}{c}\text { Padrões de } \\
\text { Relevo (\%) }\end{array}$} & $\begin{array}{c}\text { Ocupação } \\
\text { em 1950 } \\
(\%)\end{array}$ & $\begin{array}{c}\text { Ocupação } \\
\text { em 1980 } \\
(\%)\end{array}$ & $\begin{array}{c}\text { Ocupação } \\
\text { em 2010 } \\
(\%)\end{array}$ & $\begin{array}{c}\text { Áreas } \\
\text { ocupadas } \\
\text { com } \\
\text { restrições } \\
(\%)^{*}\end{array}$ & $\begin{array}{c}\text { Áreas } \\
\text { com } \\
\text { ocupação } \\
\text { urbana } \\
(\%)\end{array}$ & $\begin{array}{c}\text { Áreas com } \\
\text { possibilidade } \\
\text { de ocupação } \\
(\%)^{*}\end{array}$ \\
\hline Planície & 15,4 & 0,72 & 26,34 & 33,88 & 6,43 & 25,40 & 21,64 \\
\hline Colinas & $\begin{array}{c}40,9 \\
8\end{array}$ & 7,91 & 48,64 & 81,20 & 7,03 & 61,41 & 10,13 \\
\hline Morros & $\begin{array}{c}43,6 \\
2\end{array}$ & 1,12 & 8,72 & 31,25 & 1,88 & 13,19 & 49,46 \\
\hline Total & 100 & 3,84 & 27,79 & 52,13 & 4,69 & 34,83 & 29,06 \\
\hline
\end{tabular}

$\left({ }^{*}\right)$ Conforme parâmetros estabelecidos pelo quadro 1.

Elaboração: os autores.

Esse quadro nos demonstra algumas evidências percebidas empiricamente no cotidiano da cidade. A contribuição da Geomorfologia está quando o resultado traz que ainda existem áreas com possibilidade real e legal de ocupação na cidade, principalmente, nas áreas de morros. Isso porque, 
mesmo havendo declividades nessa área, é possível haver ocupação urbana, desde que com planejamento adequado. Além disso, nas áreas onde já há ocupações e loteamentos consolidados, regularizados ou não, os riscos de ocorrer algum evento ambiental são mínimos, haja vista que as áreas ocupadas de forma a transgredir a legislação não alcançam os 5\% dar ocupação.

Dessa forma aqui é apresentada uma contribuição ao município que, ao considerar os mesmos parâmetros ou promover a atualização do Plano Diretor, com um olhar para a cidade que aqui se buscou trazer, tem-se a ideia de que a cidade poderia ter uma dinâmica diferente daquela que a foi imposta a partir de 1970, quando o planejamento parece ter cessado no município.

Com as informações combinadas entre mapas, legislações e dinâmica urbana de Sapucaia do Sul, há evidências de que a tendência de crescimento é em direção aos morros, porém deve-se indicar que nesses compartimentos, em função da dinâmica geomorfológica, são áreas suscetíveis aos movimentos de movimentos de massa e aos processos erosivos que podem levar, em caso de ocupação urbana, às situações de risco.

A contribuição, de certa forma, está posta para que os gestores públicos tenham a dignidade de oferecer uma cidade melhor para os seus cidadãos, trazendo-os para o debate e fazendo-os participar da indução de uma cidade que está a muito tempo vivendo de improviso em todos os sentidos. Sabe-se que é necessário a criação de planos de prevenção para que tais áreas não sejam ocupadas de forma a acelerar os processos geomorfológicos.

Muitas das informações trazidas neste artigo foram abordadas e atualizadas a partir de uma Dissertação de Mestrado do mesmo autor. Para além das conclusões deste artigo, novas análises estão em andamento para uma Tese de Doutorado. Com isso, ter-se-á elementos aprofundados da relação legislação e as cidades no geral, e não só específica, como foi neste caso.

\section{CONSIDERAÇÕES FINAIS}

O Município de Sapucaia do Sul inicia a sua história no Século XVIII, mas é com a criação do Município de São Leopoldo que, o então Distrito, começa a ter uma relativa independência, uma vez que, o município, em conjunto com o estado, destinou um considerável volume de incentivos às indústrias. A partir daí, levando em conta a conjuntura estadual e nacional de êxodo rural para as regiões de aglomerações urbanas, Sapucaia do Sul começa a tomar forma.

Infelizmente, o processo de construção da nova cidade não considerou aspectos que seriam, mais tarde, fundamentais para uma boa dinâmica citadina. Até os anos 1970, ainda como herança de São Leopoldo, a administração municipal manteve uma política de ordenamento e de urbanização da cidade. No entanto, com o inchaço populacional e intervenções dos governos estadual e federal, além 
do apelo da opinião pública, os gestores municipais da época não conseguiram enfrentar as pressões dos outros níveis governamentais.

Dessa forma, restou aceitar a indução territorial por meio de equipamentos públicos, como a nova linha de metrô, e novos conjuntos habitacionais, como a COHAB; além da flexibilização na legislação e ausência de fiscalização no intuito de facilitar a ocupação do território atendendo a interesses privados.

Além disso, identificaram-se as formas de ocupação urbana em Sapucaia do Sul em diferentes épocas. Até 1950, época que Sapucaia era apenas um distrito do Município de São Leopoldo, os loteamentos seguiram a estrutura do relevo, tentando não ocupar as áreas de morro.

Em 1980 os loteamentos são implantados em direção ao rio dos Sinos e à região oeste da cidade, ensaiando uma pequena ocupação das áreas de morro. Mesmo que o crescimento seja de áreas a partir de onde já estivesse ocupado, alguns outros pontos na cidade receberam loteamentos que oportunizaram uma nova indução de vias urbanas.

Todavia é em 2010 que se nota a homogeneidade que as áreas urbanas alcançaram, chegando a ocupar a região de morros da cidade. Com isso, depois de duas reduções da Zona Rural, inicia-se uma nova pressão àquela região.

Mesmo que em Sapucaia do Sul não haja um estudo e tampouco um planejamento adequado em que considere as formas de relevo em sua ocupação, é possível distinguir que a evolução urbana procurou seguir locais que fossem adequados para a moradia, "deixando para depois" a ocupação em áreas de diferentes formas, isto é, passando a ocupar lugares de morros, quando as colinas já estavam ocupadas.

Além disso, as regiões metropolitanas brasileiras vêm recebendo, novamente, inúmeras políticas governamentais no intuito de promoção de uma política urbana mais eficiente. A pressão de crises econômicas pelo mundo levou o Governo Brasileiro a incentivar o consumo a fim de proteger a economia nacional. No entanto, todo esse incentivo está esbarrando nas dificuldades que já haviam nas cidades, quando era menor o número de carros circulando pelas ruas e mínima concentração urbana em glebas distantes do centro.

Da forma como está o andamento das políticas governamentais, esse método de ocupação urbana, "ocupar onde está vazio", tende a continuar. E não é todo o lugar vazio que é passível de receber novos assentamentos urbanos, sejam eles de qualquer padrão. É justamente aí que os mapas geomorfológicos podem contribuir diante dessa pressão. Ao identificar quais as formas de relevo estão presentes na cidade, será possível justificar que tipos de usos que o respectivo terreno poderá 
ter. É uma forma da ciência, e, sobretudo a Geografia, contribuir socialmente com o dia a dia das nossas cidades.

A complexidade de uma cidade está não só nas relações socioeconômicas que estabelecem sobre o solo. A forma como se deu a ocupação em Sapucaia do Sul, deixou áreas que estão ociosas, não só por serem vazios urbanos, mas devido a existência de uma infraestrutura adequada para loteamentos e ou outras formas de ocupação.

A identificação das áreas e formas de ocupação urbana em Sapucaia do Sul, considerando o relevo urbano, demonstrou-se que, ao que parecia nítido no cotidiano do município, ainda há áreas que poderiam haver a ocupação urbana legal a partir da situação estabelecida de expansão na cidade. Considerando ser um município inserido em um contexto metropolitano, tinha-se a ideia de que as áreas onde já estão consolidadas, poderiam haver muitos pontos em ocupação inadequada, o que esse estudo não confirmou, haja vista que o índice não alcançou os 5\% de ocupação.

A partir de uma espacialização daquilo que pode e não pode ser ocupado na cidade, é possível perceber que nem tudo, em um território, tem de cumprir alguma função urbana, conforme mostrou o mapa de tendências de ocupação que, mesmo algumas áreas estando "livres", há pontos que são impedidos de serem ocupados, sejam esses impedimentos legais e/ou ambientais. As cidades têm suas limitações e o ser humano não tem o total controle sobre elas. Nos lugares em que se tenta ter o controle sobre a natureza, muitas vezes perde-se a batalha e coloca-se em risco inúmeras vidas.

\section{REFERÊNCIAS}

ALLGAYER, Eni. História de Sapucaia do Sul. Porto Alegre: MERCOSUL, 1992.

ALLGAYER, Eni. Sapucaia do Sul, 300 anos de História. Sapucaia do Sul: Secretaria Municipal de Coordenação e Planejamento, 1988. 547 p.

AMARAL, Rosângela; ROSS, Jurandyr Luciano Sanches. A Classificação Taxonômica do Relevo como um Instrumento de Gestão Territorial - Uma aplicação ao Parque Estadual do Morro do Diabo, Município de Teodoro Sampaio (SP). In: VI Simpósio Nacional de Geomorfologia - SINAGEO, 2006, Goiânia. Anais do VI Simpósio Nacional de Geomorfologia - SINAGEO, 2006.

AMORIM Filho, Osvaldo Bueno; SERRA, Rodrigo Vieira. O recente desempenho das cidades médias no crescimento populacional urbano brasileiro. (Relatório de pesquisa do projeto "Crescimento econômico e desenvolvimento urbano"). Rio de Janeiro: IPEA, 1997.

ANDREIS, Renato Rodolfo; LAVINA, E. L; PAIM, P.S. Geologia da Folha São Leopoldo. Subprojeto IV: Mapeamento Geológico, Estratigráfico, Recursos Minerais e Paleontologia do Permiano Superior e Trifásico do RGS. Convênio UFRGS-FINEP. 1983. 
ARGENTO, Mauro Sérgio F. Mapeamento Geomorfológico. In: GUERRA, Antônio José Teixeira; CUNHA, Sandra Baptista. (Orgs.). Geomorfologia: uma atualização de bases e conceitos. 5a Ed. Rio de Janeiro: Bertrand Brasil, 2003.

BRASIL. Censo Demográfico 2010. Instituto Brasileiro de Geografia e Estatística. 2010.

BRASIL. Lei n. 6.766, de 19 de dezembro de 1979. Dispõe sobre o Parcelamento do Solo Urbano e dá outras providências. Diário Oficial da União, Brasília, DF, 20 dez. 1979.

BRASIL. Lei n.o 10.257, de 10 de julho de 2001. Regulamenta os arts. 182 e 183 da Constituição Federal, estabelece diretrizes da política urbana e dá outras providências. Diário Oficial da União, Brasília, DF, 11 jul. 2001.

BRASIL. Lei n.o 12.651, de 25 de maio de 2012. Estabelece normas gerais sobre a proteção da vegetação, áreas de Preservação Permanente e as áreas de Reserva Legal; a exploração florestal, o suprimento de matéria-prima florestal, o controle da origem dos produtos florestais e o controle e prevenção dos incêndios florestais, e prevê instrumentos econômicos e financeiros para o alcance de seus objetivos. Diário Oficial da União, Brasília, DF, 28 mai. 2012.

BRASIL. Política Nacional de Desenvolvimento Urbano. Ministério das Cidades. Brasília: Ministério das Cidades, 2004.

BRASIL. Processo de Criação da RPPN - Reserva Particular do Patrimônio Natural Fazenda Morro de Sapucaia. Instituto Brasileiro do Meio Ambiente e dos Recursos Naturais Renováveis. 2002.

CASSETI, Valter. Ambiente e Apropriação do Relevo. São Paulo: Contexto, 1991.

CASSETI, Valter. Geomorfologia. 2005. Disponível em: <http://www.funape.org.br/ geomorfologia/>. Acesso em: 20 de outubro de 2010.

DIAS, Tielle Soares. A Expansão da Ocupação Urbana sobre o Relevo do Município de Porto Alegre - RS. Trabalho de Graduação - Instituto de Geociências, Departamento de Geografia. Universidade Federal do Rio Grande do Sul, Porto Alegre, 2011.

FLORENZANO, Teresa Galloti. Cartografia. In: FLORENZANO, Teresa Galloti. (org.). Geomorfologia: conceitos e tecnologias atuais. São Paulo: Oficina de Textos, 2008.

FUNDAÇÃO João Pinheiro. Déficit Habitacional no Brasil. 2ed. Centro de Estatísticas e Informações: Brasília, 2006.

FUJIMOTO, Nina Simone Vilaverde Moura. Alterações Ambientais na Região Metropolitana de Porto Alegre - RS: um estudo geográfico com ênfase na geomorfologia urbana. In: NUNES, João Osvaldo Rodrigues; ROCHA, Paulo César. (Orgs.). Geomorfologia: aplicação e metodologias. São Paulo: Expressão Popular, 2008.

GONÇALVES, Felipe de Sousa. Mapeamento Geomorfológico como Subsídio à Análise Socioambiental do Município de Sapucaia do Sul - RS. Trabalho de Conclusão de Curso - Instituto de Geociências, Departamento de Geografia. Universidade Federal do Rio Grande do Sul, Porto Alegre, 2013. 
GUERRA, Antônio José Teixeira; MARÇAL, Mônica dos Santos. Geomorfologia Ambiental. Rio de Janeiro: Bertrand Brasil, 2006.

JORGE, Maria do Carmo O. Geomorfologia Urbana: conceitos, metodologias e teorias. In: GUERRA, Antônio José Teixeira. (org.). Geomorfologia Urbana. Rio de Janeiro: Bertrand Brasil, 2011. 280p.

LEFEBVRE, Henri. A revolução urbana. Belo Horizonte: UFMG, 1999.

MOURA, Nina Simone Vilaverde. Estudos Geográficos com Ênfase na Geomorfologia: Questões Teóricas, Metodológicas, Mapeamentos e Aplicações em Estudos Ambientais. In: Brazilian Geographical Journal: Geosciences and Humanities research medium, Uberlândia, 2011.

MUNHOZ, Andrea Elena Pizarro. Desafios da urbanização no Brasil. In: Encontro Nacional de Economia Política, 10. Campinas, Anais... Campinas (SP), 25 p, 2005. Disponível em: http://www.sep.org.br/artigo/xcongresso.83.pdf. Acesso em 16 de agosto de 2010.

OBSERVATÓRIO das Metrópoles. As metrópoles no Censo de 2010: novas tendências? Disponível em: <http://www. observatoriodasmetropoles.ufrj.br>. Acesso em: 31 jan. 2012.

PADILHA, Iranelci. Sapucaia do Sul: Homens e Origens. Porto Alegre: Martins Livreiro, 2000. 158p.

PENTEADO, Adriana de Fátima. Análise Ambiental da Bacia Hidrográfica do Arroio Kruze - Região Metropolitana de Porto Alegre - RS. Dissertação (Mestrado em Geografia) - Instituto de Geociências, Programa de Pós-Graduação em Geografia. Universidade Federal do Rio Grande do Sul, Porto Alegre, 2006.

REHBEIN, Moisés Ortemar. Análise Ambiental Urbana: Vila Augusta/Viamão/RS. 2005. 172 f. Dissertação (Mestrado em Geografia) - Instituto de Geociências, Programa de Pós-Graduação em Geografia. Universidade Federal do Rio Grande do Sul, Porto Alegre, 2005.

RIO GRANDE DO SUL (Estado). Lei n. ㅇ 9.519, de 21 de janeiro de 1992. Institui o Código Florestal do Estado do Rio Grande do Sul e dá outras providências. Diário Oficial do Estado do Rio Grande do Sul, Porto Alegre, 22 jan. 1992.

RIO GRANDE DO SUL (Estado). Lei n. ㅇ 11.520, de 03 de agosto de 2000. Institui o Código Estadual do Meio Ambiente do Estado do Rio Grande do Sul e dá outras providências. Diário Oficial do Estado do Rio Grande do Sul, Porto Alegre, 04 ago. 2000.

ROSS, Jurandyr Luciano Sanches. Geomorfologia: ambiente e planejamento. São Paulo: Editora Contexto, 2005. 8a Ed. (Coleção Repensando a Geografia).

ROSS, Jurandyr Luciano Sanches. O Registro dos Fatos Geomorfológicos e a Questão da Taxonomia do Relevo. Revista do Departamento de Geografia, 6, São Paulo: FFLCH/USP, 1992. 17-29p.

ROSS, Jurandyr Luciano Sanches; FIERZ, Marisa de Souto Matos. Algumas Técnicas de Pesquisa em Geomorfologia. In: VENTURINI, Luis Antonio Bittar. (Org.) Praticando Geografia: Técnicas de Campo e Laboratório. São Paulo: Oficina de Textos, 2005. 
SANTIAGO, Alina Gonçalves; SQUERA, Jorge Rebollo; NUNES, Caroline Pieper. Ocupação da Ilha de Santa Catarina e os Índices de Densidade Demográfica Previstos no Plano Diretor. In: PEREIRA, Elson Martins (org.). Planejamento Urbano no Brasil: conceitos, diálogos e práticas. Chapecó: Argos, 2008.

SAPUCAIA DO SUL. Lei N. o 2.896, de 11 de outubro de 2006. Institui o Plano Diretor, suas diretrizes, adequando-o ao Estatuto das Cidades e dá outras providências. Prefeitura Municipal de Sapucaia do Sul: 2006.

SUERTEGARAY, Dirce Maria Antunes; FUJIMOTO, Nina Simone Vilaverde Moura. Morfogênese do Relevo do Estado do Rio Grande do Sul. In: VERDUM, Roberto; BASSO, Luís Alberto; SUERTEGARAY, Dirce Maria Antunes. Rio Grande do Sul: paisagens em transformações. Porto Alegre: Editora da UFRGS, 2004.

SWYNGEDOUW, Erik. A Cidade como um Híbrido: natureza, sociedade e "urbanização-ciborgue". In: ACSELRAD, Henri (Org.). A duração das cidades: sustentabilidade e risco nas políticas urbanas. Rio de Janeiro: Lamparina, 2009. 2a Ed.

THOURET, Jean-Claude. Avaliação, prevenção e gestão dos riscos naturais nas cidades da América Latina. In: VEYRET, Yvette. Os Riscos: o homem como agressor e vítima do meio ambiente. São Paulo: Contexto, 2007.

Trabalho enviado em 24 de maio de 2015.

Aceito em 26 de julho de 2015. 